\title{
A Study In Relationship Orientation And Prioritization Of Alumni Association Preferences With College Seniors In Higher Education
}

\author{
Nile M. Khanfar, Nova Southeastern University, USA
}

Ziad Swaidan, University of Houston Victoria, USA

Bahaudin G. Mujtaba, Nova Southeastern University, USA

\begin{abstract}
Higher education institutions need to create a relationship with their alumni; however, often this outreach is done without adequate data on which to base decisions. To gain a better understanding of what activities future alumni may regard as both important and enjoyable for their participation as alumni, a survey of current senior-status undergraduate students of a medium-sized public southern university was conducted. The research consisted of an exploratory questionnaire with 108 senior-level students who participated in the survey. The survey consisted of information collected regarding their attitudes towards what the priorities of the university's alumni association should be and personal recommendation of the university to their friends and relatives. The survey's findings help identify the needs and preferences of those who are soon to be alumni, and point to a number of areas that can be pursued further in an attempt to improve the relationship between the university and its alumni.
\end{abstract}

Keywords: Alumni, education relationship orientation, college seniors, alumni association, university graduates, higher education, networking.

\section{INTRODUCTION}

$Q$ niversity alumni may make strong contributions to the welfare of their alma mater. One of the most important ways they contribute is through financial donations. However, another important contribution is through their participation in various university functions. Involvement in events held specifically for alumni may help breed strong esprit de corps among this group. Such types of involvement are considered the very backbone of higher learning institutions. Alumni are also able to play a very important role in support of their institution through serving as a strong source of positive word of mouth publicity. Therefore, higher education institutions must always be concerned that they effectively market to their alumni in order to foster healthy relationships between graduates and their alma mater (Mujtaba and Mujtaba, 2004). In this manner the universities have become a service provider and must endow value to their alma maters. Value is defined as relative worth or importance. Relationship orientation or relationship marketing is very important for institutions of higher education and may be defined in many different ways. In general, relationship orientation is about continuously working to attract, maintain, retain, and enhance the organization's ties or links with its end-users and/or customers (Morse and Mujtaba, 2008). In other words, relationship orientation is about the ongoing process of creating value for individual customers and society.

An effective marketing effort can begin with those students who are about to become alumni. This is the fertile ground upon which the long-lasting postgraduate relationship must be built. Universities have to realize that their role does not end with a "short term transaction/orientation" but rather has to evolve to a "long-term relationship-building goal." The cornerstone of institutions' marketing strategy is getting close to identifying and 
satisfying the needs of their diverse consumer/customer/alumni (Mujtaba and Mujtaba, 2004). If these students are not appropriately primed for their alumni relationship with their institution, it may be difficult to later engender the affection and harness the participation needed to build deep mutual support. Through research aimed at discerning students' interests, better activities may be designed which may lead to greater commitment and participation.

In every customer relationship, according to Johnson and Weinstein (2004), there are five key variables: trust, commitment, cooperation, dependence, and information exchange. These variables hold true for the alumni and university relationship as well. First, there must be a certain level of trust between current alumni and future alumni. In this situation, future alumni must have a certain level of trust that the current alumni association will be looking out for future alumni best interests as well as the school's interests. Future alumni want to know that after graduation, there will be some sort of networking and a recruitment program for prospective students.

The second variable is commitment. Both students and alumni must commit to each other to further their relationship with the school. For example, alumni associations should vow to assist future alumni with opportunities in different career fields and fundraising efforts for the school. Students and alumni should go hand-in-hand. Graduated students should want to give back to their alma mater and help as much as they can. The school can provide a wealth of opportunity.

Along with commitment goes cooperation. They are almost one and the same. Students, alumni, and universities all working together for the same goal will only enhance those opportunities for success. Well built alumni programs can offer substantial information about and provide financial assistance to the school and students. Even such things as scholarships and grants can be distributed to students to further their academic careers, providing a chance for further success and in turn commitment to their school for such an opportunity.

Dependence is the fourth variable in relationships. As relationships grow stronger, students and alumni both will be willing to put more time and effort into building a successful relationship. Students may become reliant upon alumni for guidance as graduation approaches. Alumni in turn should embrace this relationship and look forward to having future "brothers/sisters." More knowledge, funds, and resources will be gained as alumni plow forward with networking and recruiting.

As in any relationship, the exchange of information is a key driver. Surveys, such as the Stanford questionnaire, can provide sufficient amounts of information to alumni association as to how to proceed. Such surveys can provide information as to what future alumni are looking for after graduation. Alumni associations can take this information and tailor new programs toward meeting those needs/wants. Essentially, current students can drive the alumni focus toward newer, more modern outlooks in the alumni/student/school relationship. Over the years, these driving forces will change. As the Stanford study has shown, newer alumni have a more technologically based outlook on the future. Attitudes and desires change over time. So too will the alumni programs need to change.

\section{LITERATURE REVIEW}

Universities have recognized the need to have a strong relationship with their alumni. The benefits are manifold. For example, a 1994 study by Stanford's Office of Development found that the relatively low alumni giving rate among bachelor degree holders was more the result of alumni disengagement than unhappiness with the university or its policies. What the study showed was not that alumni were unhappy about Stanford, but that they simply didn't feel a part of it. Alumni didn't feel that the university took much interest in them. The conclusion was that the university and the alumni association needed to develop better means to engage alumni meaningfully as the years go by. The survey found that annual giving by Stanford alumni was the result of a chain reaction that began with the four undergraduate years on campus. Alumni satisfaction with their undergraduate experience was the single most essential pre-condition for giving - those who were not satisfied were, without exception, nondonors, according to the report (Stanford University News Service, 1994).

Many universities routinely conduct alumni studies to assess outcomes and provide information to increase the effectiveness of the university and students' quality of education. Some universities even segment their alumni 
into younger and older cohorts for surveying. For example, Georgia Tech surveyed its alumni who had graduated within the last 10 years, and found that more recent alums had different interests, different needs, and different perspectives than those who graduated decades before them. Georgia Tech's younger alumni were success-minded, upwardly mobile, technologically savvy with an entrepreneurial spirit - but close-fisted when it came to giving (Dunn, 1999).

According to the Performance Enhancement Group (2006), a consulting organization that conducts Internet-based research by distributing surveys to each participating school's alumni, an email is sent to a select group of individual alumni to introduce the survey and to provide hyperlink access to the survey. Over 150,000 alumni have been surveyed with response rates varying from $15 \%$ to over $30 \%$.

While there has often been much attention given to alumni from association offices, there has been much less focus on university students who are about to become alumni. This study was conducted to gather information on such soon-to-be alumni at one university.

\section{Methodology}

This research study was conducted to gain a better understanding of the interests of senior-level students in the types of alumni-sponsored activities that might be offered. This research provides the alumni association an opportunity to better meet senior students' expectations and to ultimately develop satisfied contributors. The researchers designed a survey instrument which was pre-tested in a focus group setting with eight students of varying backgrounds representing the population of interest. The focus group gave direction and clarified the uses of the project. Two important issues discussed in the group were alumni association functions and the overall image of the university.

The resulting questionnaire covered the following issues: (1) ranking priorities of the university alumni association, (2) determining the students' level of awareness about the university alumni association, (3) ascertaining the types of events and their scheduling that would be of interest to prospective alumni, and (4) finding out whether these students would recommend the university to a friend or a relative. The survey was conducted on the university campus. Senior class students were sampled by this study because they are the closest to graduate and become alumni. A purposive sample of 14 senior level undergraduate classes was selected from various university colleges in order to obtain data. Next, seven undergraduate classes were randomly drawn from the 14 classes to participate in the survey. Instructors confirmed that these classes consist mainly of senior students. This ensured fair representation of the senior class population at the university. Ultimately, 108 qualified surveys were included in the study.

The research sought to find out what activities could be sponsored by the association that students would regard as both important and enjoyable. The survey included a brief inventory of prospective university alumni engagement in activities, including the times and frequency of the desired activity in which they might wish to participate in. Their expected attendance reflects their interests and their support for the university's efforts to build strong interaction and relationships with alums.

\section{Data Analysis And Discussions}

Data from the completed surveys were entered into an Excel spread sheet and then the data were imported to SAS JUMP IN for analysis. Descriptive statistics were used to evaluate each item based on the mean, median, and standard deviation. Students were presented with the items to rank $(1=$ "least important" to $8=$ "very important") indicating what they thought the priorities of the university alumni association should be, yielding the results obtained in Table 1 .

Each student's response was then added to secure a total score. The next step was to array these total scores and select some portion representing the highest and lowest total scores, i.e. the top $25 \%$ and the bottom $25 \%$. These two extreme groups represent people with the most important and least important attitudes toward what they think the priorities of the university alumni association should be. The extremes were the two criterion groups by which 
the researchers evaluated individual statements. Through a comparative analysis of response patterns to each statement by members of these two groups, we learned which statements consistently correlate with most important and lowest important attitudes toward priorities of the university alumni association duties. Ranking orders of what responding students deemed as least and most important are listed in Tables 1,2 and 3. Descriptive and information statistics are presented in Tables 2 and 3.

Table 1 - Recommended Priorities of Alumni

\begin{tabular}{|c|c|c|c|c|}
\hline & Mean & Rank & Median & SD \\
\hline 1. Providing travel opportunities & 3.574 & $(8)$ & 2.5 & 2.805 \\
\hline 2. Organizing social events for networking among alumni & 4.185 & $(7)$ & 4.0 & 2.038 \\
\hline 3. Actively recruiting students & 4.814 & $(3)$ & 5.0 & 2.628 \\
\hline 4. Mentoring students & 4.740 & $(4)$ & 5.0 & 2.241 \\
\hline 5. Communicating information about the university to Alumni & 4.944 & $(2)$ & 5.0 & 1.816 \\
\hline 6. Supporting university athletic program & 4.388 & $(5)$ & 4.0 & 2.059 \\
\hline 7. Representing university in the local community & 4.981 & $(1)$ & 5.0 & 2.398 \\
\hline 8. Being involved in political action on behalf of university & 4.370 & $(6)$ & 4.0 & 1.983 \\
\hline
\end{tabular}

Institutions of higher education need to take a proactive approach to market their services to future alumni in order to reap financial benefits and enhance the brand equity of the university. This approach starts while students are still enrolled in the school. The first step is to make students aware of the existence of the Alumni Association and further their services. This study illustrates a considerable lack of awareness among senior students as one third of survey participants (38/108) were not aware of the existence of the alumni association. Awareness may be enhanced by posting banners on stands or booths during such events as sports activities and crawfish boils. The study findings support the notion that $38.9 \%$ of future alumni selected crawfish boils as their most favorite alumni function to attend.

Table 2 - Frequency Calculations for Demographic Questions of Alumni

\begin{tabular}{|l|c|c|}
\hline \multicolumn{1}{|c|}{ Frequency } & Percentage (\%) \\
\hline Gender & 28 & 25.9 \\
\hline Male & 80 & 74.1 \\
\hline Female & 108 & 100.0 \\
\hline Total & \multicolumn{2}{|c|}{} \\
\hline Ethnic & 86 & 20.4 \\
\hline White & 22 & 100.0 \\
\hline Non-White & 108 & 16.7 \\
\hline Total & & 38.9 \\
\hline Major & 18 & 25.9 \\
\hline Arts and Sciences & 42 & 18.5 \\
\hline Business Administration & 28 & 100.0 \\
\hline Education \& Human Development & 20 & \\
\hline Health Sciences & 108 & \\
\hline Total &
\end{tabular}

The second most favorite alumni feature was athletic events. A major exposure which was ranked number one in respondents' ranking is "Representing university in the local community." Such representation by the alumni association and its members will not only enhance the university brand name but also add to the social responsibility the school has toward the community it lives with. Future alumni also want the alumni association to communicate with them and basically stay in touch with them. This was evident as respondents' selected "Communicating information about the university to alumni" as the second highest priority for the alumni association to do. Future alumni want to hear news about their university. That indicates the amount of interest and affection they have for 
the schools. It is also a sign of a positive feeling toward their school as $79.6 \%$ of respondents indicated that they will recommend the school to a friend or a family relative.

Table 3 - Frequency Calculations for Information Questions of Alumni

\begin{tabular}{|c|c|c|}
\hline \multicolumn{3}{|c|}{ Awareness of Alumni Association } \\
\hline Aware & 68 & 64.8 \\
\hline Not Aware & 38 & 35.2 \\
\hline Total & 108 & 100.0 \\
\hline \multicolumn{3}{|c|}{ What type of Events would you like to Attend? } \\
\hline Luncheon & 10 & 9.3 \\
\hline Formal Dinner & 8 & 7.4 \\
\hline Family Events (w/kids) & 20 & 18.5 \\
\hline Athletic Events & 24 & 22.2 \\
\hline Crawfish Boil & 42 & 38.9 \\
\hline Homecoming Reception & 4 & 3.7 \\
\hline Total & 108 & 100.0 \\
\hline \multicolumn{3}{|c|}{ What are the best times for you to meet? } \\
\hline During the week & 22 & 20.4 \\
\hline Weekend & 54 & 50.0 \\
\hline Happy hour reception & 4 & 3.7 \\
\hline Evening after hours & 28 & 25.9 \\
\hline Total & 108 & 100.0 \\
\hline \multicolumn{3}{|c|}{ How often would you like to attend university alumni association events? } \\
\hline Once a Month & 34 & 31.5 \\
\hline Once a Quarter & 24 & 22.2 \\
\hline Twice a Year & 36 & 33.3 \\
\hline Only at Homecoming & 4 & 3.7 \\
\hline Not at all & 10 & 9.3 \\
\hline Total & 108 & 100.0 \\
\hline \multicolumn{3}{|c|}{ Would you recommend the university to a friend or family relative? } \\
\hline Yes & 86 & 79.6 \\
\hline No & 22 & 20.4 \\
\hline Total & 108 & 100.0 \\
\hline
\end{tabular}

Future alumni overwhelmingly indicated willingness to attend the alumni association function. When asked "How often would you like to attend university alumni association events?" $87 \%$ of respondents indicated their interest to attend the functions more than once a year. Again, this response affirms the degree of interest and satisfaction the students have with their school.

The third highest priority for the alumni association is to actively recruit students (Mean $=4.814)$. Future alumni perceived this item to be important for the association to perform. However, next to last on the list (\# 7) of priority was interestingly "Organizing social events for networking among alumni." One would think that this would be a sought-after function; however, it was not perceived as a high priority for the alumni association to do.

Alumni association events are crucial for universities' long term success and growth, especially for state universities. Many universities depend on generous alumni contributions to establish scholarships for students and chairmanships for faculty to subsidize their income. For example, Harvard University has over 20 billion dollars in its trust fund as contributions from alumni.

\section{Limitations}

Several limitations exist in the research study presented. Chief among them is that the sample of respondents was small. A wider survey needs to be conducted before any decisions are to be made to check for 
representativeness. Although the research was designed to be only exploratory in nature, there may be the tendency to implement decisions based on the limited findings. Moreover, it should be recognized that these soon-to-bealumni are only one piece of the alumni puzzle. The alumni association must also obtain input from other segments of interest. Nevertheless, graduating seniors could be an important segment, because if they are not solidified at this stage, they may be difficult to harness for some time.

Gathering information from an institution's diverse students can be extremely fruitful for a university (Wilson and Mujtaba, 2008). Future studies should attempt to gather data from a more diverse population of senior college students since this study's respondents were mostly females and people from a White ethnicity.

\section{CONCLUSION}

The need for higher education institutions to proactively create a healthy relationship with their alumni cannot be overemphasized. This paper has shown that future alumni tend to regard certain relationship orientation activities as both important and enjoyable for their continuous involvement with the university. The research discussed in this paper consisted of an exploratory questionnaire with senior-level students who participated in the study. The paper discussed senior students attitudes towards activities they thought were important and presented recommendations. This type of research helps to identify the needs and preferences of those who are going to be alumni and points to a number of areas that can be pursued further in an attempt to improve the relationship between the university and its alumni.

\section{AUTHORS INFORMATION}

Dr. Nile M. Khanfar is an assistant professor at Nova Southeastern University College of Pharmacy in West Palm Beach campus. He received his Ph.D. in Pharmacy Administration from the University of Louisiana at Monroe Dr. Khanfar has presented several podium and poster presentations at national and international Business and Pharmacy conferences. His research interest includes topics in the fields of marketing, management and healthcare. His work has been published in several peer-reviewed business and pharmacy journals.

Dr. Ziad Swaidan is an associate professor of marketing at the University of Houston-Victoria. Dr. Swaidan received his Ph.D. in marketing from the University of Mississippi. His cross cultural research has appeared in the Journal of Business Ethics, Journal of Marketing Theory and Practice, Journal of Global Marketing, International Business Review, Journal of Education for Business in addition to many other journals and refereed proceedings. Dr. Swaidan was awarded the University of Houston-Victoria Excellence in Research and Scholarly Activity Award in 2006.

Dr. Bahaudin G. Mujtaba is Department Chair and an Associate Professor of Management, Human Resources Management, and International Management at Nova Southeastern University's H. Wayne Huizenga School of Business and Entrepreneurship. For the past twenty-two years, Bahaudin has served as manager, trainer and management development specialist in the corporate world as well as a director, department chair and faculty member in academia. His areas of research are management, leadership, customer service, training, diversity management, and cross-cultural management.

\section{REFERENCES}

1. Henke, H. \& Russum, J. (2000). Factors influencing attrition rates in a corporate distance education program. Education at a distance, 14 (11), Article 03. Retrieved July 25, 2007 from

http://www.usdla.org/ED magazine/illuminactive/ NOV00_Issue/ story03.htm

2. $\quad$ Dunn, J. (2006). "Portrait of Young Alumni." Retrieved on 12, 16, 2006 from: http://gtalumni.org/news/ttopics/fall99/survey.html.

3. Khanfar, N. M.; Swaidan, Z.; and Mujtaba, B. G. (2008). Relationship orientation and prioritization of alumni association activities by college seniors. Global Academy of Business \& Economic Research Proceedings; September 18, 2008; Orlando, Florida. 
4. Johnson, W. C. \& Weinstein, A. (2004). Superior Customer Value in the New Economy. Boca Raton: CRC Press.

5. Marquand, B. (2004). Ask Questions before Heading to Graduate School. South Florida Business Journal: Guide to Education. July $16^{\text {th }} 2004$.

6. Morse, T. C. and Mujtaba, B. G. (September 2008). The Challenge of Recruiting and Retaining Teachers in the United States: Is this a Compensation or Demand Issue? Contemporary Issues in Education Research Journal; 1(3), pp. 1-10. ISSN: 1940-5847.

7. Mujtaba, B. \& Mujtaba, L. (2004). Creating a Healthy Learning Environment for Student Success in the Classroom. The Internet TESL Journal. Vol. X, No. 2. The article can be retrieved via the following URL link: http://iteslj.org/ or: http://iteslj.org/Articles/Mujtaba-Environment.html.

8. Performance Enhancement Group Ltd (2006). Alumni Attitudinal Study. Retrieved on 12, 16, 2006 from: http://www.pegltd.com/images/pdfs/AAS about the study.pdf.

9. Stanford University News Service, "Survey Looks at Factors that Affect Alumni Giving." Retrieved on 12, 16, 2006 from: http://www.stanford.edu/dept/news/pr/94/941213Arc4016.html.

10. Wilson, S. D. and Mujtaba, B. G. (June 2008). Intelligence and Diversity: A Western and Eastern View from a Global Paradigm. International Business and Economics Research Journal, Vol. 7, No. 6; pages 2939. 
NOTES 